\title{
PENERAPAN TEKNIK MENIRU MODEL DALAM PEMBELAJARAN MENULIS NASKAH PIDATO
}

\author{
Siwi Astini ${ }^{1}$, Intan Sartini ${ }^{2}$ \\ SMP Negeri 30 Bandung $^{1}$, IKIP Siliwangi Bandung ${ }^{2}$ \\ Surel: siwiastini@yahoo.co.id ${ }^{1}$ \\ intan.satriani@yahoo.co.id ${ }^{2}$
}

\begin{abstract}
Abstrak
Kemampuan mengungkapkan ide dan gagasan dalam menulis naskah pidato sangat penting untuk diajarkan dan dikuasai oleh peserta didik di era globalisasi saat ini. Sehubungan dengan hal tersebut, penelitian ini mengangkat model pembelajaran menulis naskah pidato dengan teknik meniru model. Oleh karena itu, tahapan persiapan dalam eksperimen ini berupa model pembelajaran dengan teknik meniru model. Penelitian dilakukan dengan metode eksperimentasi. Pelaksanaan metode ini dilakukan melalui tahapan teknik pengumpulan data melalui studi literatur. Hasil yang diperoleh ternyata silabus yang dibuat sudah baik karena memang disusun berdasarkan kurikulum 2004. Model pembelajaran yang disiapkan sudah sesuai sehingga dapat dijadikan contoh bagi guru-guru bahasa dan sastra Indonesia di SMP. Kegiatan belajar mengajar yang dilakukan ternyata berkadar CBSA tinggi dan benarbenar dapat menciptakan iklim yang kondusif bagi siswa untuk menguasai materi pembelajaran. Hal ini dapat dilihat dengan adanya perubahan wawasan dan kemampuansiswa ketika pretes dan postes. Rata-rata nilai siswa ketika pretes adalah 5.8 sedangkan postes sebesar 9.87 dengan selisih sebesar 4.07. Hal tersebut menunjukkan bahwa terdapat pengaruh positif dari treatment yang diberikan. Tingkat pencapaian indikator hasil pembelajaran 95\%. Penelitian ini menyarankan bahwa teknik meniru model dalam pembelajaran menulis lebih diperluas dengan tingkat imajinatif yang lebih tinggi dengan lebih mengeksplorasi kreatifitas siswa yang variatif.
\end{abstract}

Kata Kunci: naskah pidato, teknik meniru model

\section{Pendidikan Bahasa, Sastra \\ Abstract Daerah}

The ability to express ideas in writing speech script is very important to be taught and mastered by learners in the current era of globalization. In connection with this, this research raises the learning model of writing a speech script with an imitation model technique. Therefore, the preparation stage in this experiment is a model of learning by imitating the model. The research was done by experimental method. The implementation of this method was done through the stages of data collection techniques through literature study. The results obtained turns out that the syllabus made is good because it is compiled based on the 2004 curriculum. The prepared learning model is appropriate so that it can be used as an example for Indonesian 
language and literature teachers in junior high school. Teaching and learning activities conducted turned out to be high CBSA level and can create a conducive climate for students to master learning materials. It can be seen with the change of insight and the ability of students when the pretest and postest. The average students' score when pretest is 5.8 whereas postest is 9.87 with a difference of 4.07 . It shows that there is a positive effect of treatment given. Achievement level of learning result indicator 95\%. This research suggests that the modeling technique in writing learning is further expanded with higher imaginative levels by exploring the creativity of varied students.

Keywords: speech script, model mimic techniques

\section{PENDAHULUAN}

Agar lulusan Pendidikan Nasional memiliki keunggulan kompetitif dan kooperatif sesuai dengan standar mutu nasional dan internasional, maka Departemen Pendidikan Nasional menetapkan sebuah perangkat kurikulum tingkat nasional yang dikenal dengan Kurikulum 2004. Kurikulum 2004 mata pelajaran bahasa dan sastra Indonesia adalah salah satu program untuk mengembangkan pengetahuan, keterampilan berbahasa, dan sikap positif terhadap bahasa dan sastra Indonesia.

Tujuan mata pelajaran bahasa dan sastra Indonesia, (1) Sarana pembinaan kesatuan dan persatuan bangsa, (2) Sarana peningkatan pengetahuan dan keterampilan dalam rangka pelestarian dan pengembangan budaya, (3) Sarana peningkatan pengetahuan dan keterampilan untuk meraih dan mengembangkan ilmu pengetahuan, tek nologi, dan seni, (4) Sarana penyebar luasan pemakaian bahasa dan sastra Indonesia yang baik untuk berbagai keperluan, (5) Sarana pengembangan penalaran dan (6) Sarana pemahaman keberagaman budaya Indonesia melalui khasanah kesastraan Indonesia.

Pengajaran bahasa Indonesia meliputi aspek kemampuan berbahasa yaitu (1) Kemampuan mendengar (listening skill), (2) Kemampuan ber- bicara (speaking skill), (3) Kemampuan membaca (reading skill), (4) Kemampuan menulis (writing skill). Sebenarnya keempat aspek tersebut dapat dibagi menjadi dua kelompok besar yaitu keterampilan yang bersifat menerima meliputi kemampuan menyimak dan membaca serta keterampilan menulis dan berbicara. Dari keempat aspek keterampilan bahasa tersebut, keterampilan menulis mempunyai peranan yang tak kalah penting dengan aspek keterampilan bahasa lainnya.

Dalam pembicaraan mengenai menulis tentu kita tidak lepas dari kegiatan membaca, penulis yang mem-punyai daya ekspresi tinggi tentu akan lebih bervariatif dalam menuangkan ide, gagasan, pendapat dan perasaan pada tulisannya. Dengan demikian, menulis mempunyai peranan yang sangat penting dalam menuangkan ide, gagasan begitu pula dalam pembelajaran menulis tidak terkecuali dalam menulis naskah pidato untuk sambutan disesuaikan dengan konteks tujuan dan pendengar dengan memperhatikan penggunaan pilihan kata dan kalimat yang sesuai serta dapat membawakannya.

Kemahiran berbahasa seseorang dapat didukung oleh adanya proses pembelajaran untuk memahami kai- 
dah yang berlaku didalam suatu bahasa. Dalam kehidupan sehari-hari, kita dapat temukan bahwa kekomunikatifan suatu bahasa sering terganggu dengan adanya pemahaman yang salah sehingga menimbulkan tanggapan yang tidak sesuai. Untuk dapat mendorong dan mengatasi hal tersebut, upaya pembinaan dan pengembangan bahasa indonesia khususnya ketrampilan menulis perlu mendapat perhatian sebaik-baiknya.

Mengingat pentingnya masalah tersebut dan berlandaskan pada pemikiran maka penulis memilih judul "Model pembelajaran menulis naskah pidato dengan teknik meniru model kelas IX SMP Negeri 4 Serang, Banten."

Mempelajari pidato tidak hanya merupakan aktifitas para pejabat namun setiap individu dan masyarakat bahasa perlu belajar berpidato. Berkaitan dengan perkembangan budaya dan pengetahuan, pada hakekatnya budaya dipelajari dari suatu tulisan. Namun, ada juga penyampaian tulisan secara lisan yang dikenal dengan seni berpidato.

Kemampuan bicara bukan hanya diperlukan di depan sidang parlemen, di muka hakim atau dihadapan massa. Kemampuan ini dihajatkan dalam hampir seluruh kegiatan manusia sehari-hari. Hal tersebut didukung|oleh pernyataan Rah- (2001:2) yang menyatakan bahwa realisasi dari pendapat ini bahwasanya pidato bukan hanya di gedung-gedung parlemen atau kantor birokrasi dan biro politik. Dia juga mengatakan bahwa pidato merupakan komunikasi lisan yang amat penting bagi kelangsungan budaya. Se-mentara itu, Arsjad \& Ridwan (1997:53) menyatakan pidato merupakan penyampaian dan penanaman pikiran, informasi atau gagasan dari pembicaraan kepada khalayak ramai.

Dalam penyampaian pidato, naskah merupakan hal yang dibutuhkan. Terdapat empat definisi naskah, pertama naskah didefinisikan sebagai karangan yang masih ditulis dengan tangan. Selain itu, naskah merupakan karangan seseorang sebagai karya asli. Naskah juga sebagai bahan-bahan berita yang siap untuk diset. Terakhir, naskah bisa disebut juga sebagai rancangan.

Berdasarkan pendapat diatas, dapat disimpulkan bahwa naskah pidato adalah karangan berupa tuntutan tentang bahan-bahan informasi atau gagasan untuk disampaikan secara lisan kepada kelompok-kelompok atau khalayak ramai untuk mencapai gagasan dan tujuan tertentu.

\section{Teknik Membuat Konsep Pidato}

Dalam membuat pidato, terdapat beberapa hal yang perlu diperhatikan salah satunya yaitu teknik membuat konsep pidato. Djanaid (1994:104) membagi teknik ini menjadi tiga hal yaitu persiapan, membuat konsep pidato dan ciri pidato bermutu. Pertama, naskah pidato tidak bisa langsung jadi tetapi butuh persiapan. Persiapan ini bisa dilakukan dengan cara membaca buku, mencatat ungkapan yang menarik, mencatat pandangan baru, mengumpulkan fakta, menguasai masalah, dan membuat konsep. Setelah tahap persiapan, penulis naskah pidato bisa mulai membuat konsep pidato. Pertama yang dibutuhkan adalah kerangka pidato yang meliputi garis-garis besar diantaranya judul, tujuan umum, dan materi. Kedua yaitu tujuan umum. Bagian ini berisi pengertian apa yang diharapkan dari pendengar. Bagian terakhir dari 
kerangka pidato yaitu materi yang berisi ide atau gagasan yang akan disampaikan untuk mendukung tujuan.

Selain kerangka, dalam proses pembuatan konsep pidato penulis juga perlu mengetahui struktur pidato. Susunan struktur pidato terdiri dari pembukaan (salam, pengarahan terhadap peristiwa, maksud dari pidato), uraian atau isi (ide utama, gagasan pendukung, alasan, penjelasan, bukti, perbandingan), dan penutup.

Hal terakhir yang perlu diketahui yaitu ciri-ciri pidato yang bermutu. Pertama, tujuan pidato jelas dan materinya sesuai dengan tema atau judul. Kedua, butir utama merupakan manifestasi dari cara kreatif, induktif, deduktif, kausetif, dan problem solving. Ketiga, butir pendukung bersifat komprehensif artinya dapat menjelaskan dari berbagai aspek dan aspek tersebut syaratnya dengan hal-hal yang baru atau variasi dari setiap butir pertama.

\section{METODE}

Penelitian ini menggunakan metode kuantitatif. Metode ini diimplementasikan untuk mengetahui apakah penerapan metode meniru model signifikan diterapkan pada pembelajaran menulis. Terdapat dua instrumen dalam penelitian ini yaitu treatment dan tes. Tes terdiri dari dua macam diantaranya pretest dan posttest. Penelitian ini dilaksanakan di kelas IX D SMPN 4 Serang, Banten.

\section{HASIL DAN PEMBAHASAN}

Dalam penelitian ini terdapat dua variabel data yaitu nilai pretes dan postes. Untuk melihat perbedaan dua jenis tes tersebut, penulis melakukan uji " $t$ " dengan rumus yang diambil dari Arikunto (1998).

$$
\mathrm{t}=\frac{\mathrm{Md}}{\frac{\sqrt{\sum \mathrm{X}^{2} \mathrm{~d}}}{\mathrm{~N}(\mathrm{~N}-1)}}
$$

Keterangan :

$\mathrm{Md}=$ mean dari perbedaan pretes

dan postes (pretes-postes)

$\mathrm{Xd} \quad=$ devisi masing-masing subjek

(d-Md)

$\mathrm{d}=$ Gian (pretes-postes)

$\sum \mathrm{X}^{2} \mathrm{~d}=$ Jumlah kuadrat deviasi

$\mathrm{N} \quad=$ Subjek pada sampel

d.b. =ditentukan dengan $\mathrm{N}-1$

Tabel Analisis Kuantitatif

\begin{tabular}{|c|c|c|c|c|c|c|}
\hline No & $\begin{array}{l}\text { Nama } \\
\text { Siswa }\end{array}$ & Pre & Post & D & Xd & $\mathbf{X d} d^{2}$ \\
\hline 1. & $\begin{array}{c}\text { Ade } \\
\text { Rohmah }\end{array}$ & 4,8 & 7,5 & 2,7 & $-1,37$ & 3,13 \\
\hline 2. & Ade FS & 4 & 7,8 & 3,8 & $-0,27$ & 0,07 \\
\hline 3. & Albet A & 6,3 & 8,5 & 2,2 & $-1,82$ & 3,50 \\
\hline 4. & Aldi R & 4 & 8 & 4 & $-0,07$ & 0,01 \\
\hline 5. & Aria $\mathrm{M}$ & 4 & 8 & 4 & $-0,07$ & 0,01 \\
\hline 6. & $\begin{array}{c}\text { Candra } \\
\text { B P }\end{array}$ & 4,8 & 7,5 & 2,7 & $-1,77$ & 3,13 \\
\hline 7. & Desak P & 6 & 8,5 & 2,5 & $-1,57$ & 2,46 \\
\hline 8. & Dita L & 4,8 & 8,5 & 3,7 & $-0,37$ & 0,14 \\
\hline 9. & Een $\mathrm{S}$ & 6,6 & 8,5 & 1,9 & $-2,17$ & 4,17 \\
\hline 10. & Eva R & 7,8 & 9,6 & 2 & $-2,07$ & 4,28 \\
\hline 11. & Ferrianto & 4,8 & 7,8 & 3 & $-1,07$ & 1,14 \\
\hline 12. & Fitria & 5,8 & 9,2 & 3,4 & $-0,67$ & $\begin{array}{c}- \\
0,45 \\
\end{array}$ \\
\hline 13. & Gina D & 5,5 & 8,5 & 3 & $-1,07$ & 1,14 \\
\hline 14. & $\begin{array}{c}\text { Graveta } \\
\mathrm{C}\end{array}$ & 6,8 & 9,3 & 2,5 & $-1,57$ & 2,46 \\
\hline 15. & $\begin{array}{c}\text { Gumilar } \\
\mathrm{P} \\
\end{array}$ & 4,8 & 8,3 & 3,5 & $-0,57$ & 0,32 \\
\hline 16. & Hendri S & 4,8 & 8,2 & 3,4 & $-0,67$ & 0,45 \\
\hline 170 & hcHeru Nas & 7,6 & 9,5 & 1,7 & $-2,37$ & 5,61 \\
\hline d8. & Jumhadi & 4,8 & 8,3 & 3,5 & $-0,57$ & 0,35 \\
\hline 19. & K Dewi & 6 & 8 & 2 & $-2,07$ & 4,28 \\
\hline 20. & Lody & 7,3 & 9,5 & 2,2 & $-1,87$ & 3,50 \\
\hline 21. & Lendy $\mathrm{H}$ & 4 & 7,5 & 3,5 & $-0,57$ & 0,32 \\
\hline 22. & $\begin{array}{c}\mathrm{M} \\
\text { Ristandi }\end{array}$ & 4 & 7,1 & 3,1 & $-0,97$ & 0,94 \\
\hline 23. & Merin M & 7 & 9,4 & 2,4 & $-1,67$ & 2,79 \\
\hline 24. & $\begin{array}{c}\text { Mia } \\
\text { Mita S }\end{array}$ & 5,5 & 8 & 2,5 & $-1,57$ & 2,46 \\
\hline 25. & M Faisal & 6,8 & 8,5 & 1,7 & $-2,57$ & 5,61 \\
\hline 26. & M Iqbal & 6,8 & 9 & 2,2 & $-1,87$ & 3,50 \\
\hline 27. & $\begin{array}{l}\text { Nela } \\
\text { Dewi }\end{array}$ & 7 & 9,4 & 2,4 & $-1,67$ & 2,79 \\
\hline 28. & $\begin{array}{c}\text { Nila } \\
\text { Hidayat }\end{array}$ & 6 & 8,5 & 2,5 & $-1,67$ & 2,46 \\
\hline
\end{tabular}




\begin{tabular}{|c|c|c|c|c|c|c|}
\hline No & $\begin{array}{l}\text { Nama } \\
\text { Siswa }\end{array}$ & Pre & Post & D & Xd & $X d^{2}$ \\
\hline 29. & $\begin{array}{c}\text { Nila } \\
\text { Kemala }\end{array}$ & 4,8 & 7,4 & 2,6 & $-1,47$ & 2,16 \\
\hline 30. & $\begin{array}{c}\text { Nurmail } \\
\text { a Sari }\end{array}$ & 7,5 & 9,2 & 7,1 & $-2,37$ & 5,61 \\
\hline 31. & $\begin{array}{c}\text { Nurfina } \\
\mathrm{H}\end{array}$ & 7 & 9,2 & 2,2 & $-1,87$ & 3,50 \\
\hline 32. & $\begin{array}{c}\text { Osi } \\
\text { Sanjaya }\end{array}$ & 5,6 & 7,8 & 2 & $-2,07$ & 4,28 \\
\hline 33. & Pinki M & 6 & 8,5 & 2,5 & $-1,57$ & 2,46 \\
\hline 34. & Ria S & 6,3 & 8 & 1,7 & $-2,37$ & 5,61 \\
\hline 35. & Rita S & 7,3 & 9,2 & 1,9 & $-2,17$ & 4,71 \\
\hline 36. & $\begin{array}{c}\text { RT } \\
\text { Haylatun } \\
\end{array}$ & 5,5 & 7,8 & 2,3 & $-1,77$ & 3,13 \\
\hline 37. & Siti M & 5,5 & 8 & 2,5 & $-1,57$ & 2,46 \\
\hline 38. & $\begin{array}{c}\text { Sri Dewi } \\
\mathrm{K}\end{array}$ & 7 & 9,2 & 2,2 & $-1,87$ & 3,50 \\
\hline 39. & $\begin{array}{c}\text { Sri Rizki } \\
\text { U }\end{array}$ & 6,8 & 8,5 & 1,7 & $-2,37$ & 5,61 \\
\hline 40. & Suhartati & 8 & 9,8 & 1,8 & $-1,95$ & 3,28 \\
\hline 41. & Tantri T & 7,3 & 9,3 & 2 & $-2,07$ & 4,28 \\
\hline 42. & $\begin{array}{c}\text { Taufik } \\
\text { H. }\end{array}$ & 4,8 & 7,2 & 2,4 & $-1,67$ & 2,79 \\
\hline 43. & $\begin{array}{c}\text { TB } \\
\text { Hafid }\end{array}$ & 4,8 & 7,2 & 2,4 & $-1,67$ & 2,79 \\
\hline 44. & $\begin{array}{c}\mathrm{TB} \\
\text { Sandi } \\
\end{array}$ & 5,3 & 7,8 & 2,5 & $-1,57$ & 2,46 \\
\hline 45. & Widya $\mathrm{H}$ & 5,4 & 7,8 & 2,4 & $-1,67$ & 2,79 \\
\hline 46. & $\begin{array}{c}\text { Willy } \\
\text { TR }\end{array}$ & 4,7 & 7,2 & 2,5 & $-2,57$ & 2,46 \\
\hline 47. & Yuliana & 6,3 & 8 & 1,7 & $-2,37$ & 5,61 \\
\hline \multicolumn{2}{|c|}{ Jumlah } & $\begin{array}{c}272 \\
, 5\end{array}$ & $\begin{array}{c}463, \\
7\end{array}$ & $\begin{array}{l}19 \\
1,5\end{array}$ & & $\begin{array}{c}132, \\
39\end{array}$ \\
\hline
\end{tabular}

$\operatorname{Md} \quad \frac{=\sum \mathrm{d}}{N}=\frac{191,5}{47}=4,07$

$\mathrm{t}=\frac{\mathrm{Md}}{\frac{\sqrt{\sum \mathrm{X}^{2} \mathrm{~d}}}{\mathrm{~N}(\mathrm{~N}-1)}}$

$\mathrm{t}=16,28$

Melihat daftar nilai tabel " $t$ " untuk $\mathrm{N}=47$ yaitu 2,68 dalam taraf kepercayaan $95 \%$. Dengan demikian, $\mathrm{t}$ hitung 16,28 > dari t tabel $=2,68$. Jadi, penerapan teknik meniru model untuk mengajarkan menulis naskah pidato pada siswa SMP memberikan pengaruh yang signifikan. Dari hasil analisis pembelajaran dapat terlihat penguasaan siswa untuk setiap aspek yang dinilai. Selain itu, dapat pula dibaca perbandingan ketika pretes dan postes. Dengan menganalisis setiap aspek tersebut dapat diungkapkan penguasaan kompetensi dasar oleh siswa sebelum kegiatan belajar mengajar dan sesudahnya.

Dengan demikian, peningkatan penguasaan untuk setiap aspek dapat terlihat. Secara klasikal rata-rata pretes 5,80 sedangkan rata-rata postes 9,87 . Hal ini menunjukkan bahwa siswa telah menguasai indikator hasil belajar dengan selisih 4,07. Berdasarkan analisis diatas dapat disimpulkan bahwa siswa telah menguasai kompetensi dasar yang diajarkan. Perubahan kompetensi siswa sebelum kegiatan belajar mengajar dan sesudahnya terlihat sejalan dengan hasil penelitian. Oleh karena itu, pertanyaan penelitian "apakah penerapan teknik meniru model dapat diterapkan dalam pembelajaran menulis pidato di kelas IX SMP Negeri 4 Serang?". Hasilnya telah menjawab teknik tersebut dapat diimplementasikan dengan baik dan menjawab hipotesis.

\section{PENUTUP}

\section{Simpulan}

Secara umum penelitian ini dapat disimpulkan bahwa penyusunan model pembelajaran dengan menggunakan teknik model berdasarkan kurikulum 2004, setelah diujicobakan dalam suatu kegiatan belajar mengajar terhadap siswa kelas IX SMP Negeri 4 Serang dapat dinyatakan berhasil. Hal tersebut dibuktikan dengan tingkat perbedaan signifikan antara pretes dan postes. Hasil belajar siswa kelas IX pada kompetensi dasar menulis naskah pidato dengan model pembelajaran yang menggunakan teknik meniru model berdasarkan kurikulum 2004 ternyata cukup baik. Rata-rata pretes 
5,80 sebelum penerapan kegiatan belajar mengajar, dan nilai rata-rata postes mencapai 4,07 pada taraf kepercayaan $95 \%$. Hal ini menunjukkan bahwa terdapat pengaruh positif dari treatment yang diberikan. Tingkat pencapaian indikator hasil pembelajaran $95 \%$.

\section{Saran}

Pada penelitian lain disarankan untuk menggunakan teknik meniru model dalam pembelajaran menulis lebih diperluas dengan tingkat imajinatif yang lebih dengan mengeksplorasi kreatifitas siswa yang variatif. Dalam hal ini, perlu juga dipertimbangkan pengetahuan prasyarat yang harus dikuasai siswa demi menentukan tingkat keluasan teknik model.

\section{DAFTAR PUSTAKA}

Arikunto, S. 1997. Prosedur Penelitian Suatu Pendekatan Praktek. Jakarta: PT. Rineka Cipta.

Arsjad, M. G. \& Ridwan, S. H. 1997. Menulis. Jakarta: Depdikbud, RI.

Djanaid, D. (1994). Kepemimpinan Teori Dan Praktek. Malang: Indopurels Training.

Rakhmat, J. (2001). Retorika modern. Bandung: Remaja Rosdakarya. 